\title{
THE EFFECTIVENESS OF SCHOOLOGY ON TECHNOLOGY SKILLS: E-LEARNING INTEGRATION IN EDUCATION
}

\author{
${ }^{1}$ Rully Putri Nirmala Puji, ${ }^{2}$ Desi Priyanti \\ 1,2 History education, Universitas Jember, Indonesia \\ rully@unej.ac.id \\ Jember, East Java, Indonesian
}

\begin{abstract}
Schoology is an e-learning platform that offers several exciting features that can be optimized by educators and students in tandem with parents. This can be one of the media in optimizing strong communication between the three. Schoology is also able to be one of the pathways to improving the skills in utilizing the technology of students who have also become one of the demands of the 4.0 revolution. Schoology is able to be used by educators in particular types of education and in certain subjects. This study aims to identify the effectiveness of Schoology on the technology skills of students in higher education ranking. The research results have shown that Schoology poses an effect on improving technology skills in aspects of text formatting and searching the web.
\end{abstract}

\section{Keywords: E-Learning; Schoology; Technology Skills}

\begin{abstract}
Abstrak
Schoology merupakan salah satu platform e-learning yang menawarkan beberapa fitur menarik yang dapat dioptimalisasi oleh pendidik dan peserta didik bersama dengan orang tua. Hal ini mampu menjadi salah satu media dalam mengoptimalkan komunikasi yang intens antara ketiganya. Schoology juga mampu menjadi salah satu cara dalam meningkatkan keterampilan pemanfaatan techmology peserta didik yang turut menjadi salah satu tuntutan dari revolusi 4.0. Schoology mampu dimanfaatkan oleh seluruh pendidik dalam jenjan pendidikan tertentu dan dalam mata pelajaran tertentu. Penelitian ini bertujuan untuk mengidentifikasi efektifitas schoology terhadap technology skills peserta didik di peringkat pendidikan tinggi. Hasil penelitian menunjukkan bahwa schoology memberikan effect terhadap peningkatan technology skills pada aspek text formatting dan searching the web.
\end{abstract}

Keywords: Keterampilan Teknologi; Pembelajaran online; Schoology 


\section{INTRODUCTION}

The development of the Industrial Revolution 4.0 in this digital era requires all parties to be adaptive to the use of technology. Implementation of technology in education can be actualized through the use of e-learning based learning processes. Based on the results of a survey on 30 students in tertiary education, empirics show that the evaluation using e-learning in the lecturing is still very rare with a mean value of 2.13 (SD = 0.82). Industrial revolution 4.0 requires all aspects to utilize information-technology in all lines. Education is one of the aspects that really need the use of technology to improve the quality of learning (Puji, 2015; Puji 2019). This needs to be explored in more depth, whether all educators already have the awareness and knowledge of the importance of the existence of the use of technology in this digital age. Utilization of technology in the learning process can be implemented through the mastery of communication languages, disseminating ideas, and information through technical assistance and making learning systems accessible to anyone and anywhere (Hussin, 2018).

Indonesia is ranked seventh out of 10 ASEAN countries (Association of Southeast Asian Nations) in terms of information technology development index (Boekaerts, M, 2002). This shows that Indonesia needs to improve itself in seeking ways to improve the quality of information technology. The country with the highest technology development index in the ASEAN region is Singapore. This country is able to adapt information technology satisfactorily. The low index of information technology development in Indonesia also has an impact on the low index of human development.

The number of internet users in Indonesia has increased in the last five years. Based on the results of a survey conducted by the Indonesian Internet service providers association, the level of student internet use is still very low. This is indicated by the value of the composition of student internet use by $7.8 \%$, with a total of 10.3 Million users. This is certainly inversely proportional to the assumption that students should have higher intensity in accessing the internet, for example, such as searching for learning resources, articles, and journals as well as the use of e-learning.

Schoology is one of the e-learning arsenals that can function as a medium of learning, a source of learning, evaluation of learning, and a tool of communication among educators, students, and parents (Creswell, 2017; Alamsyah, 2020; Hidayah; 2020; Puji 2018). Schoology is an e-learning tool that can provide some interesting features needed to provide excellent facilities in the learning process. Schoology has several advantages, compared to other elearning tools. Research conducted by Sarrab, et al classifies the advantages of Schoology based on five categories, including availability, usability, dependability, functionality, and performance. The Schoology has the advantage of providing English, which is an 


\section{Journal Publicuho}

ISSN2621-1351 (online), ISSN 2685-0729 (print)

Volume 4 Number 2 (May-July), (2021)pp. 511-519

Accredited SINTA SK.NOMOR 28/E/KPT/2019

Open Access at:http://ojs.uho.ac.id/index.php/PUBLICUHO/index

DOI: 10.35817/jpu.v4i2.18093

international language in 135 countries. This makes it easy for users to communicate globally and internationally (Sarrah, 2015).

Schoology in principle has the advantage of having a good integration connection with several accounts or other applications such as Google Docs, Google Drive, and so on. This certainly accrues a positive value and results in optimizing the use of Schoology in learning. Access to save files using the cloud will make it easier for educators and students to share files and documents such as learning resources, learning material or test kits, etc.

Schoology access to Turnitin also educates students to be able to account for the work done academically from the effects of plagiarism. In this usability principle, it seems that Schoology also has shortcomings, pertinent to uploading of tasks that are slightly delayed when the content contains filling images and videos in large file capacities.

The third principle is Dependability. In this principle, it seems that Schoology has a disadvantage, it is difficult for users to modify the features and appearance desired, and according to their needs. This is certainly different from the Moodle application, which provides advantages and opportunities for educators to adapt the e-learning Moodle to the learning needs. Schoology on the principle of Functionality has advantages compared to other e-learning tools. Schoology has good functional value. This requires the support and cooperation of related parties to provide good functional value. Schoology has high functional value as long as it is integrated well with the school's reporting and supervision system and the information system under the school management and its users' government (Sarrah, 2015; Puji 2018).

Based on the evaluation of Schoology's performance, this platform is found to offer easily accessible online by using social networking platforms. This will have a positive impact on academic users, namely increased communication development and collaboration capabilities for each user. This is caused by features and easy access to Schoology that can create a conducive and intense learning process.

The era of digitalization encourages people to utilize technology in all aspects. This relates to the need for globalization of fast work access and data management to be better coordinated. Technological developments need to be adjusted to the needs and interests of education itself (Taleb, 2013; (Puji, 2018); Puji 2020). The need for mastery of technology in one particular field has differences from other fields. The mastery of technology in education needs to be adjusted to the needs of the students themselves (Pintrich 1999, Pintrich 2003). Indicators of technology skills in education according to Taleb include (1) familiarity with data security; (2) entering text; (3) basic concepts of internet and browser; (4) file management; (5) using the word processor; (6) basic file management concepts; (7) working with icons; (8) formatting a text; (9) navigation of web pages; (10) familiarity with copyright \& data 
protection; (11) searching the web; (12) text editing with software; and (13) basic concepts of electronic communication and Bookmark a webpage (Talleb, 2013).

\section{METHODOLOGY}

This study aims to identify the effectiveness of the application of Schoology to students' technology skills. Technology skills in this study focus on aspects of formatting text and browsing the web (Talleb, 2013). This study deploys an experimental research design involving 30 students in tertiary institutions. Table 1 displays the demographic data in the study. This research uses quantitative data analysis using SPSS, a paired sample T-test.

Table 1. Demographic Data

\begin{tabular}{llll}
\hline No & Demographic & $\mathbf{N}$ & \% \\
\hline 1 & Male & 15 & $50 \%$ \\
2 & Female & 15 & $50 \%$ \\
\hline
\end{tabular}

This study makes use of an achievement test as the data collection instrument. Students had to sit a pre-test to measure their technology skills in aspects of formatting text and searching the web. After that, the educators were required to implement Schoology and gave a post-test at the end of the learning. The test conducted to test students' ability in formatting text involved designing historical infographics and searching the web for collecting reputable international journals aimed to develop History learning materials. Preand post-test tests were carried out using paired sample t-test with data analysis aids in the form of SPSS (Statistical Product and Service Solutions) (Cleland, 2005).

\section{RESULTS AND DISCUSSION}

\section{Schoology}

E-Learning employs the assistance of services/electronic devices. e-Learning is a web application that utilizes the internet. e-Learning has a flexible value in its use even though it is limited by distance and internet network capabilities. Schoology is an e-learning tool that can be utilized by all educators in all subjects. The first step to register for Schoology is to go to the page https://www.Schoology.com/ to register for a Schoology account. After going to the page above, the next step is to choose the type of account that is as a teacher/instructor, student/learners, and the third is the parents. In this section, we pretend to register as a teacher to find out what features can be utilized in the learning process.

The registration process is done by entering an email and password account in accordance with the users' needs. The verification process is done by sending a notification to the e-mail registered. This process is essential to ensure that account stability and verification can be carried out properly. In addition, we can also get notifications of the latest information about Schoology updates via email. After the registration process is complete, the next step is creating a class. The process of adding classes is adjusted to the class level and the academic level of students. 


\section{Journal Publicuho}

ISSN2621-1351 (online), ISSN 2685-0729 (print)

Volume 4 Number 2 (May-July), (2021)pp. 511-519

Accredited SINTA SK.NOMOR 28/E/KPT/2019

Open Access at:http://ojs.uho.ac.id/index.php/PUBLICUHO/index DOI: 10.35817/jpu.v4i2.18093

The next step is to add materials to the Schoology account. Schoology has materials with religious types including (1) assignment; (2) quiz; (3) file or external tool; (4) discussion; (5) page; (6) album media; and (7) package. Schoology has the advantage of providing facilities for loading multiple learning resources in various formats such as (1) file/document; (2) link; (3) PowerPoint slide; (4) picture; (5) photo; and (6) video. Quiz and evaluation forms that can be accessed in Schoology include the following: (1) true-and-false items; (2) multiplechoice questions; (3) ordering; (4) short answer; (5) fill in the blank; (6) matching.

Schoology is an e-learning platform that has complete facilities and features. Schoology is one of the e-learning programs that are of interest to educators and students. This is due to the completeness of features such as learning games, quizzes, and some interesting material (Sugiyanto, 2018). Schoology has numerous similarities with Edmodo. Both of them offer complete features in helping the learning process. Schoology and Edmodo have their own advantages and disadvantages compared to others. Broadly speaking, students are more motivated by the use of media or mobile and electronic-based learning platforms. Time and duration of learning also contribute to the success of learning (Brinkerhoff,2006). Schoology has advantages in terms of effective use of time and duration. Schoology can be accessed quickly, anywhere, and anytime.

The educational aspect needs to utilize the use of technology as a learning device. Today's education has placed technology as a medium and source of learning that can increase learning productivity (Sanchez, 2018; vibulphol, 2016). Educators apply technology not only for administrative purposes and office matters but also for instructional purposes. The readiness to use technology is also one of the success factors in learning. Educators' skills and knowledge also influence the use of technology in learning (Randal, 1999). The use of technology in learning needs to be optimized and evaluated for effectiveness (Russel, 2006; Boekaerts, 2002; Cleland,2005). Evaluation of the use of technology in education serves to improve the quality of learning to meet the needs of students and learning objectives (Russel, 2006). Educators need technology that varies in each learning to create interactive classes. Some learning practices utilizing technology are laden with developing interactive websites, processing information and databases, creating discussion forums, and communicating using email.

\section{The Effectiveness of Schoology for Propelling Students' Technology skills}

The pre-test is conducted for students in the history of education in the higher education ranking. The test is conducted with the assessment of the technical skills of students on aspects of formatting text and searching the web. The following chart shows the results of the pre-test and post-test carried out.

Tests using paired sample t-tests belong to the parametric statistical tests. Before carrying out 
DOl: 10.35817/jpu.v4i2.18093

paired sample t-test on the ability of text formatting and searching the web of students, the initial step is to satisfy the assumptions or requirements for parametric statistical tests. These requirements and assumptions are tests of normality. The table showcases the normality test results.

Diagram 1. Technology skills test

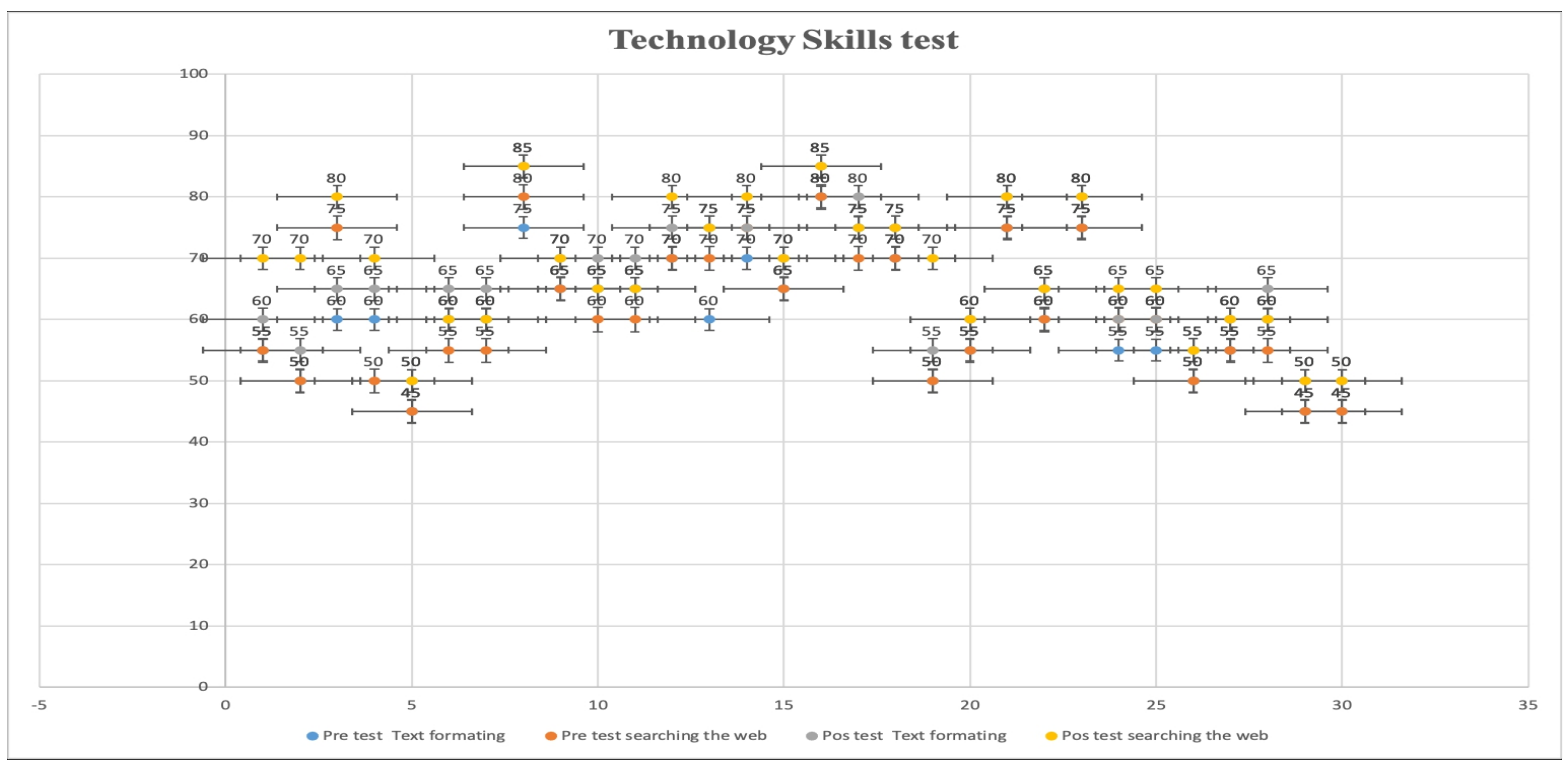

Table 2. Data Normality Test

\begin{tabular}{lcccccc}
\hline & \multicolumn{3}{c}{ Kolmogorov-Smirnov $^{\mathbf{a}}$} & \multicolumn{3}{c}{ Shapiro-Wilk } \\
\cline { 2 - 7 } & Statistic & p. & Sig. & Statistic & df & p. \\
\hline Pre TF & 0,141 & 30 & 0,134 & 0,954 & 30 & 0,214 \\
Pre TF & 0,151 & 30 & 0,080 & 0,936 & 30 & 0,070 \\
Post SW & 0,125 & 30 & 0,200 & 0,956 & 30 & 0,242 \\
Post SW & 0,153 & 30 & 0,072 & 0,929 & 30 & 0,045 \\
\hline
\end{tabular}
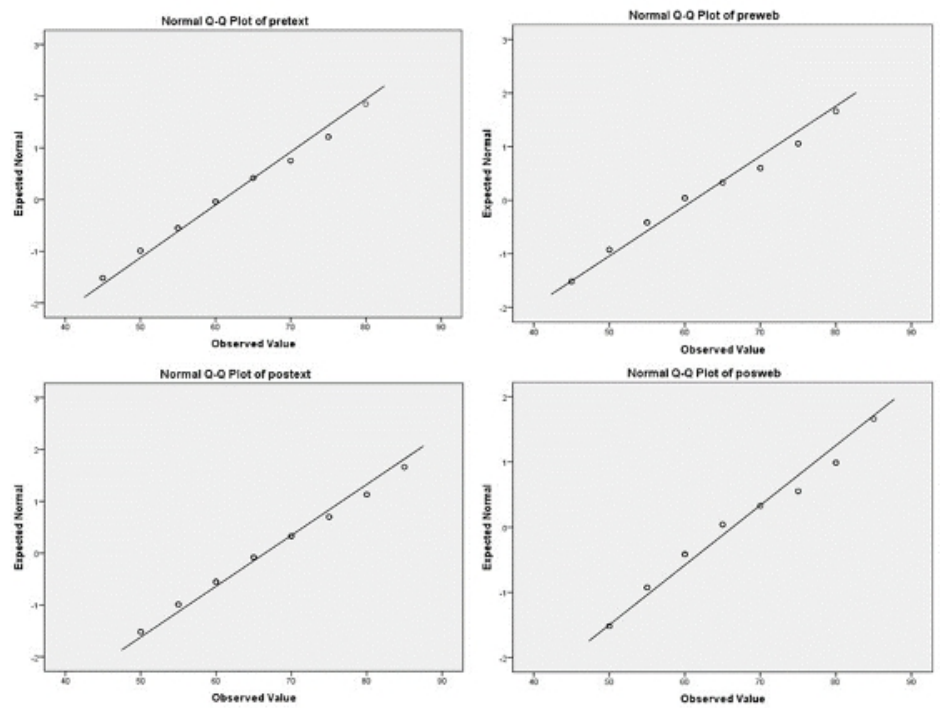

Figure 1. Normal Q-Q Plot

*TF $=$ Text formatting

SW $=$ Searching the web. 


\section{Journal Publicuho}

ISSN2621-1351 (online), ISSN 2685-0729 (print)

Volume 4 Number 2 (May-July), (2021)pp. 511-519

Accredited SINTA SK.NOMOR 28/E/KPT/2019

Open Access at:http://ojs.uho.ac.id/index.php/PUBLICUHO/index DOI: 10.35817/jpu.v4i2.18093

The normality test shows that the data are normally distributed with the Kolmogorov Smirnov value related to pre-test scores in-text formatting $=0.134>0.005$; post-test scores in searching the web $=0.080>0.005$; post-test scores in formatting text $=0.200>0.005$; pre-test scores in searching the web $=0.072>0.005$. Based on the assumption of normality, a paired sample $t$ test can be carried out. Hereunder are the results of paired sample t-test pre and post technology skills on the aspects of text formatting and searching the web.

Table 3. Paired Sample t-test of Experiment Class

\begin{tabular}{lllllllll}
\hline & $\overline{\mathbf{x}}$ & $\boldsymbol{\sigma}$ & Cor & Lower & Upper & $\mathbf{t}$ & $\mathbf{a}$ & $\mathbf{p .}$ \\
\hline PreTF & 61,00 & 9,77 & 0,980 & $-6,251$ & $-4,74$ & $-14,9$ & 0.005 & 0,000 \\
PostTF & 66,50 & 10,18 & & & & & & \\
PreSW & 61,16 & 10,72 & 0,894 & $-8,808$ & $-5,19$ & $-7,91$ & & 0,000 \\
PostSW & 68,16 & 10,12 & & & & & & \\
\hline
\end{tabular}

Eła Squared TF

$$
\begin{aligned}
& =\frac{t^{2}}{t^{2}+(\mathrm{N}-1)} \\
& =\frac{-14,966^{2}}{-14,966^{2}+(30-1)} \\
& =\frac{223.981}{223.981+(29)} \\
& =\frac{223.981}{353.982} \\
& =0,632
\end{aligned}
$$

$$
\begin{aligned}
\text { Eta Squared SW } & =\frac{\mathrm{t}^{2}}{\mathrm{t}^{2}+(\mathrm{N}-1)} \\
& =\frac{-7,918^{2}}{-7,918^{2}+(30-1)} \\
& =\frac{62,694}{62,694+(29)} \\
& =\frac{62,694}{91.694} \\
& =0,683
\end{aligned}
$$

The table above shows that there is a significant difference between pre-text and post-text scores in formatting text, $M=61.00, S D=9,773$ and $M=66.50, S D=10.183$, respectively. ${ }^{\dagger}$ (29) $=-14,966, p 0,000<0.005$ (two tailed). The increase in mean score with a $95 \%$ confidence 
interval ranges from $-6,251$ to $-4,748$. Eta squared statistics (0.632) indicate moderate effects (Cohen, 1988). In addition, this data also shows that there are significant differences between web searching $(M=61.16, S D=10.722)$ and web searching post $(M=68.16, S D=10.127), \dagger(29)$ $=-7.918, p 0,000<0.005$ (two tailed). The increase in mean 7 with $95 \%$ confidence interval ranges from $-8,808$ to $-5,191$. Eta squared statistics (0.683) indicate moderate effects [10]. The data shows that the application of Schoology is able to give effect to the improvement of technology skills aspects of text formatting and searching the web.

\section{CONCLUSIONS}

Schoology is an e-learning platform that offers several interesting features that can be optimized by educators, students, and parents in tandem. This platform can be one of the media in optimizing intense communication between the three. Schoology is also able to be one of the ways to improve the skills in utilizing the technology of students who have also become one of the demands of the 4.0 revolution. The research results have shown that Schoology offers the effectiveness of escalating students' technology skills concerned with text formatting and searching the web. Schoology needs to be applied and utilized in learning to streamline the learning process and improve students' learning outcomes.

\section{REFERENCE}

Alamsyah M R B, Puji RPN and Soepeno B 2020 Information media on historical tourism: probing into public perspectives in Jember regency IOP Conf. Ser.: Earth Environ. Sci. 485012138

Boekaerts, M. (2002). Motivation to learn. Human Resource Development Quarterly, 15(3), 127.

Brinkerhoff, J. (2006). Effects of a Long-Duration, Professional Development Academy on Technology Skills, Computer Self-Efficacy, and Technology Integration Beliefs and Practices, 39(1).

Cleland, J., Foster, K., \& Moffat, M. (2005). Undergraduate students ' attitudes to communication skills learning differ depending on year of study and gender, (May 2015). https://doi.org/10.1080/01421590400029541

Cohen, J. (1988).Statistical power analysis for the behavioral sciences (2nd ed.).Hillsdale, NJ: Lawrence Earlbaum Associates.

Creswell, J. W. (2017). Research design: qualitative, quantitative, and mixed methods approaches. (Vol. 91). SAGE Publications, Inc. All.

Hidayah B, Na'im M, Puji RPN 2020 Technological content knowledge of history teachers in Jember IOP Conf Series: Earth And Environmental Science 485012132 doi:10.1088/1755$1315 / 485 / 1 / 012132$

Hussin A A 2018 Education 4 . 0 Made Simple: Ideas For Teaching, (c), 92-98.

Randal, D., \& John, S. (1999) Mentoring Pre-Service Teachers for Technology Skills Acquisition.

Russell, G. et al. (2006). Information technology skills of Australian teachers: implications for teacher education of Australian Teachers: https://doi.org/10.1080/14759390000200087 


\section{Journal Publicuho}

ISSN2621-1351 (online), ISSN 2685-0729 (print)

Volume 4 Number 2 (May-July), (2021)pp. 511-519

Accredited SINTA SK.NOMOR 28/E/KPT/2019

Open Access at:http://ojs.uho.ac.id/index.php/PUBLICUHO/index DOI: 10.35817/jpu.v4i2.18093

Russell, G., Finger, G., Russell, N., Russell, G., Finger, G., Russell, N. Russell, N. (2006). Information technology skills of Australian teachers: implications for teacher education of Australian Teachers : https://doi.org/10.1080/14759390000200087

Pintrich, P. R. (1999). The role of motivation in promoting and susta ining self-regulated learning, 31, 459-470.

Pintrich, P. R. (2003). A Motivational Science Perspective on the Role of Student Motivation in Learning and Teaching Contexts, 95(4), 667-686.

Priskila, M., N. Umamah, RPN, Puji. 2018. Interactive Multimedia Based On Computer Assisted Instruction: Development Efforts on the Learning Interest and Effectiveness in the History Learning. Volume 5 issue 6.

Puji RPN and Ahmad AR 2015 Learning Style of MBTI Personality Types in History Learning at Higher Education Scientific Journal of PPI-UKM 3289

Puji RPN and N. Umamah. 2018. Edmodo Multimedia: Supporting Technology for Media Learning at Higher Education. International Journal of English Literature and Social Sciences.

Puji RPN and Sumarno. (2019). Plastic waste product development: Environment preservation efforts. OP Conference Series: Earth and Environmental Science. Vol 243. Issue 1

Puji RPN et al 2020 The Students' Prior Knowledge at The Department of History Education within Tertiary Education IOP Conf Series: Earth And Environmental Science 485 012041 doi:10.1088/1755-1315/485/1/ 012041

Sanchez Garcia, L. F., Sebastiá-Amat, S., Molina Garcia, N., \& Saiz Colomina, S. (2018). Schoology As an Alternative To Traditional Teaching Tools for University Students. EDULEARN 18 Proceedings, 1 (July), 7514-7520.

Sarrab, M, Al-Shihi, H., \& Al-Manthari, B 2015 System Quality Characteristics for Selecting Mobile Learning Applications. Journal of Distance Education, 16, 18-27. Sarrab,

Sugiyanto, S.A. (2018). Comparison of mobile learning applications in classroom learning in vocational education technology students based on usability testing Comparison of mobile learning applications in classroom learning in vocational education technology students based on usability testing.

Taleb, Z. (2013). Information and Communication Technology Skills Ranking in Secondary School Curriculum. Procedia-Social and Behavioral Sciences, 69(Iceepsy), 1093-1101.

Vibulphol, J. (2016). Students' Motivation and Learning and Teachers' Motivational Strategies in English Classrooms in Thailand. English Language Teaching, 9(4), 64. https://doi.org/10.5539/elt.v9n4p64

Worth, R. (2004). Communication Skills, Second Edition. 